\title{
FACTORS OF TOURIST PERCEIVED VALUE OF INDONESIA SHOPPING TOURISM
}

\author{
Filda Rahmiati ${ }^{1}$, Grace Amin ${ }^{2}$ \\ ${ }^{1}$ President University, filda.rahmiati@president.ac.id \\ ${ }^{2}$ President University, grace_amin@president.ac.id
}

\begin{abstract}
ABSTRAK
Belanja menjadi komponen rantai pariwisata yang semakin relevan. Belanja telah menjadi faktor penentu yang mempengaruhi pilihan tujuan, komponen penting dari keseluruhan pengalaman perjalanan dan, dalam beberapa kasus, motivasi perjalanan utama. Dengan adanya keinginan untuk berbelanja, pengembangan pariwisata belanja adalah fenomena yang menarik perhatian para pembuat kebijakan, akademisi dan pemimpin bisnis di seluruh dunia. Kota Bandung, sebagai salah satu kota yang disebut "surga belanja" telah menarik banyak wisatawan mancanegara (wisman). Tujuan dari penelitian ini untuk menganalisa penilaian wisatawan mancanegara terhadap loyalitas wisata belanja di Kota Bandung. Penilaian pelanggan yang digunakan berdasarkan dari penelitian sebelumnya dan di aplikasikan di wisata belanja di Kota Bandung untuk melihat factor mana saja yang dominan. Hasil dari analisa pada penelitian ini dinyatakan terdapat 5 (lima) factor baru pada penilaian wisatawan mancanegara pada wisata belanja. Kelima factor tersebut adalah: (1) Emotional Value, (2) Value for Money, (3) Social Value, (4) Hedonic Value, and (5) Functional Value. Faktor yang paling dominan yaitu Emotional Value karena memiliki nilai Eigen Value yang paling tinggi. Penelitian ini mengharapkan adanya koordinasi antara Pemerintah Kota Bandung untuk memperbaiki infrastruktur kota sehingga memberika sisi kenyamanan bagi para wisatawan mancanegara saat berkunjung ke Kota Bandung. Selain itu juga adanya inovasi dari sisi pembayaran saat berbelanja, inovasi pada pusat perbelanjaan yang diharapkan dapat menambah kepuasan wisatawan sehingga terciptanya kunjungan berulang juga merekomendasi kepada wisatawan mancanegara lainnya.
\end{abstract}

Kata Kunci: wisata belanja, penilaian pelanggan, belanja, wisatawan mancanegara

\section{ABSTRACT}

Shopping becomes a relevant component. Shopping has become a factor that influences the choice of destination, travel, travel and travel. With the desire to develop, it is an interesting phenomenon for policy makers, academics and business leaders around the world. The city of Bandung, as one of the cities called "shopping paradise" has attracted many foreign tourists (tourists). The purpose of this study is to analyze the factors of foreign tourists perceived value towards shopping tourism in the city of Bandung. The results of the analysis in this study stated that there are 5 (five) new factors of tourist perceived value of shopping tourism. The five factors are: (1) Emotional Value, (2) Value for Money, (3) Social Value, (4) Hedonic Value, and (5) 
Functional Value. The most dominant factor is Emotional Value because it has the highest Eigen Value. This research recommend coordination between the Government of Bandung City to improve the city infrastructure so as to provide comfort for foreign tourists when visiting the city of Bandung. In addition, there are also innovations in terms of payment when shopping, innovations in shopping centers that are expected to increase tourist satisfaction so the creation of repeat visits also recommends to other foreign tourists.

Keywords: shopping tourism, tourist perceived value, shopping, foreign tourist

\section{A. INTRODUCTION}

The contribution of tourism has become an essential for low and middle income nations. The importance of tourism contributes to employment opportunities in hotels, restaurants, retail establishments, and transportation (Christian et al., 2011; Kotler et al., 2010). For many countries, UNWTO (2016) stated that tourism is a source of foreign currency earnings and an important contributor to the economy, focusing on retention of the "hard-earned dollar" (Mcewen \& Bennett, 2010). Tourism believed to be one of the pillars that support governments around the world to stimulate economic growth, foreign exchange earnings, and job opportunities which involves millions of workers in the hospitality, food, transportation, tour guides, as well as craft industry (Jucan \& Jucan, 2013; Nasution \& Mavondo, 2005; PIDII, 2016). Tourism is a rapidly growing business that receives global attention. Successful tourism business will offer many benefits to the host countries. As Khuong \& Ha (2014) said that Tourism as "the smokeless industry", is one of the most essential multinational business activities in the world.

Mentioned by Yuan, Fowler, Goh, \& Lauderdale (2013) and Rifai (2014) that shopping becomes a growing related element in the tourism industry as it converted to be main motivation for travel which affects destination tourism choice. Further, Timothy (2005) stated that there are three primary factors as the driving forces behind shopping as a primary reason for travel: the merchandise being sought, the destination selected, and price advantages. One of the most popular tourist activities globally is shopping activities. Destinations such as Hong Kong and Paris, shopping has become a main tourist attraction as a primary motive for visit which contributes to the economy. 
Survey created by Hertinmalyana et al., (2012) found that most of foreign tourists always spent their time for shopping, no matter their main of purpose. Previous researchers have been studied regarding the similar field of this research, such as: the foreign tourists spending their holiday in Sri Lanka (Gnanapala, 2015), Taiwan tourist in China (Mohd et al., 2014), Tourism behavior and luxury shopping in the city of Vienna (Chen, 2013), tourist shopping behavior of domestic tourists in United States (Oh, 2007), and city branding strategy using setting of domestic and international tourists visiting Bandung (Yuwo et al., 2013). Indonesia also promoting its shopping tourism (Ministry of Tourism Indonesia, 2016), by introducing the 3 largest modern shopping tourism destinations in Indonesia which are: Festival Jakarta Great Sale, Surabaya Shopping Festival, and Semarang Great Sale also enhancing other shopping destinations hope that these events will attract more foreign tourists to visit Indonesia (PIDII, 2016).

In 2015, the Government of Indonesia provided visa-free policy to 169 countries whose citizens do not need a visa to come and live in Indonesia (for a maximum period of 30 days) (Jefriando, 2016; PIDII, 2016; Priyambodo, 2017). Meanwhile, the Government also introduced a new regulation on cruises and yachts. The new regulation abolished the obligation of sabotage for international cruise ships and yachts at the five ports of Indonesia, namely: Tanjung Priok (Jakarta), Tanjung Perak (Surabaya), Belawan (Medan) Soekarno-Hatta (Makassar) and Benoa (Bali). Although open more visa-free access to Indonesia causes the country to lose approximately USD. 11.3 million per year (as currently costs USD. 35 set for 'visa on arrival'), the action is expected to attract an additional 450,000 foreign tourists per year. Given that each tourist spends an average of between USD. 1,100 to 1,200 per person each time they visit Indonesia, the country will receive approximately USD. 500 million as an additional foreign exchange earnings annually (domestic tourists spent approximately IDR. 711,000 per trip). Other benefits from visa-free policy are increasing number of foreign tourist visit Indonesia. In 2016 counted that it increased $15.54 \%$ of foreign tourist visiting Indonesia as compared in 2015. Further, the growth of private investment as jumped drastically to $53 \%$

Additionally, neighboring countries, such as Malaysia, like to visit Indonesia because of the similarity of culture and affordable prices of Indonesia products (Puskompublik, 2012). Supported by Timothy (2005) about cross-border shopping as a travelling which may produce a 
sense of pleasure and excitement. So, the development of shopping tourism is an important drivers in international tourism.

Further, I Gede Pitara (2016) stated that every tourist has different characteristics on spending. Tourists are enjoyed with many activities either culture, nature or others. Most of them always spent their time for shopping, no matter their main of purpose as Indonesia tourism has a price competitive compare to their country. The most loyal foreign tourists in Indonesia are from China and Uni Emirate Arab. They spend less in terms of lodgings and transportation; hence, they are spending more on buying souvenirs. It is believe can contribute to the country which directly impact to the community. These create government of Indonesia to boost the economy creative to reach the demand from tourists. Exhibition, one of the examples done by government, affects positively to boost up the international tourists visit Indonesia (Hertinmalyana et al., 2012).

Today, customer orientation through perceived value. It is important for seller to emphasis on customer perceived value as it leads to customer satisfaction and customer loyalty. There are many studies regarding customer perceived value. In regard to shopping tourism, Mohammed Ismail El-Adly \& Eid (2016) created MALLVAL dimensions in order to analyses the customer perceived value consist of seven values of hedonic, self-gratification, utilitarian, transaction, epistemic, social interaction, and time convenience. Therefore, this study aims to find factors of the tourist perceived value of shopping tourism in Indonesia which based on MALLVAL dimensions which will be represented by Bandung City as a shopping paradise of Indonesia tourism.

\section{Problem Background}

In terms of tourists' spending, UNWTO (2014) reported that Asia Pacific destinations are benefiting from booming visitor numbers and high visitor spending. In fact, the region boasts some of the highest visitor expenditure on shopping as a proportion of the total travel budget. Shopping, hence, is one of the major categories of tourists' expenditure, representing a significant source of income for national economies both directly and through the many linkages to other sectors in the economy. Furthermore, Oh (2007) stated that shopping activities is a big components of travel expenditures. His study found that $85 \%$ of international tourists participate 
in shopping. In terms of total spend on all goods and services purchased while abroad, MasterCard, a valued PATA member found that Bangkok received the greatest visitor spend in the region (UNWTO, 2016a). According to the MasterCard Global Destination Cities Index 2013, the top ten Asia/Pacific cities by international visitors' cross-border spending were (in USD) are shown in Table 1. Unfortunately, Indonesia was not listed in this list. Hence, shopping tourism precisely can improve the economic conditions of local businesses such as SMEs in Indonesia as more income derived from selling products to tourists.

In fact, Indonesia also promoted its shopping tourism (Ministry of Tourism Indonesia, 2016). As an example, Bandung City, called as shopping paradise which able to attract foreign tourists. Nonetheless, data shown a decreased number of foreign tourists visited Bandung City as shown in Figure 1. In the year 2011 was the highest number of foreign tourists visiting Bandung, but in 2012 was decreased and slowly improved until 2015. Unfortunately, in 2016 it was turned down again. Based on that conditions, it should have ways on how to improve the numbers of foreign tourists to visit Bandung City in the future.

Table 1: International visitors' cross-border spending (in USD)

\begin{tabular}{cc}
\hline Cities & Tourist Spending \\
\hline Bangkok & $\$ 14.3$ billion \\
Singapore & $\$ 13.5$ billion \\
Tokyo & $\$ 12.7$ billion \\
Seoul & $\$ 10.8$ billion \\
Sydney & $\$ 10.4$ billion \\
Taipei & $\$ 8.1$ billion \\
Kuala Lumpur & $\$ 7.8$ billion \\
Shanghai & $\$ 6.9$ billion \\
Hong Kong & $\$ 6.3$ billion \\
Melbourne & $\$ 5.9$ billion \\
\hline
\end{tabular}

Source: (UNWTO, 2016b) 


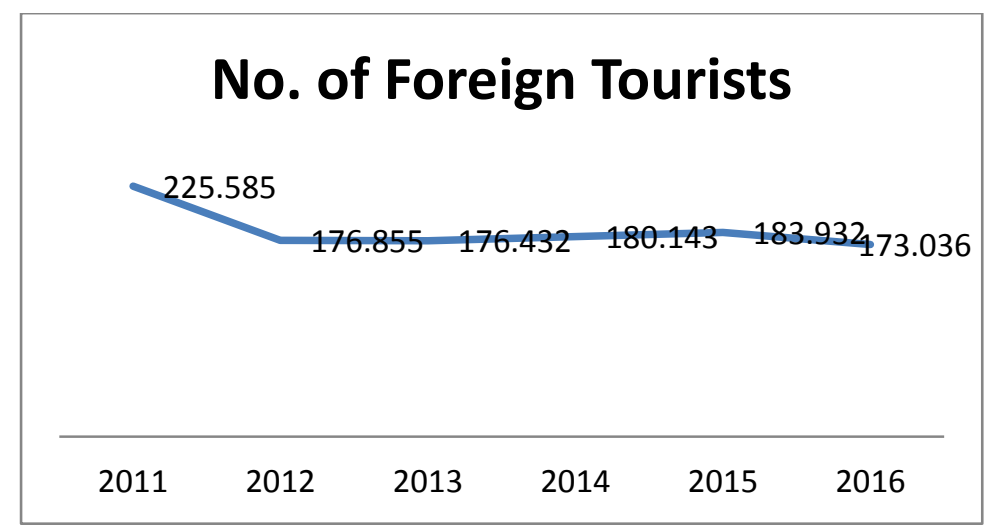

Figure 1. Number of Foreign Tourists Visited Bandung City

There are several conditions faced by Bandung City which could impacted the decreased of foreign tourists visited, such as: traffic jam, flooding, and street vendors which create discomfort for foreign tourist and lead to negative word of mouth also reducing tourist satisfaction and revisit intention (Nugroho, 2009; Seputarbandungraya.com, 2017; Detik.com, 2013).

Based on above mentioned, this study will have several objectives:

1. To find factors of tourist perceived values on shopping tourism.

2. To find the dominant factors of Tourist Perceived Value on shopping tourism.

\section{B. LITERATURE REVIEW}

\section{Shopping Tourism}

Shopping has become an important factor affects destination option, important elements in travelling, said to be main motivation for travel (Sundström, Lundberg, \& Giannakis, 2011; UNWTO, 2014). More importantly, shopping is one of the major categories of tourists' spending, contribute as a source of national income (Meng \& Xu, 2012). Tourism shopping could be an impulses activity during travel, as many factors drives tourist to purchase something during their trip such as unique store, social interactions, and tour guide. As a consequence, shopping malls play an important role in tourism, especially for the family vacation destination as shopping mall provide not only shopping but also dining and entertaining activities (Mohammed Ismail El-Adly \& Eid, 2017). 
Additionally, shopping is an gradually important aspect in tourism (Raluca \& Gina, 2003; Yuan et al., 2013). People might find very pleasurable when they can able to bargains, spending, and going somewhere involves travelling abroad, experimenting cultural differences, spending foreign currency, and different tastes of foods. The purpose of combining travel with shopping is to target tourist longer visits in order to gain a competitive advantage and create marketable image. Consequently, shopping remains one of the most interesting satisfying and stimulating form of leisure that will change the form of future travel and tourism industry.

Lastly, one of the most lucrative tourism activities is shopping (Mehta, Jain, \& Jawale, 2014), Dubai, as an example of famous and popular tourist shopping destinations. Various factors such as infrastructure of Shopping destinations, hotels and the branding strategy followed in Dubai. Hence, as tourist's behavior is changing, 'brand presence' and 'variety' are more significant as compared to 'price' and 'discounts'. Furthermore, UNWTO (2016a) mentioned an additional concept about shopping tourism. One of the trends shared was the so-called 'Bleisure' - the combination of Business and Leisure. People are likely to add a day or even a weekend to their trip for shopping activities. Diversity, price and quality, opening hours, customer orientation in shops, handicrafts and souvenirs quality were mentioned as key aspects to advance in shopping tourism.

\section{Customer Perceived Value}

Value is a function not only for costs to the customer but also of the results achieved for the customer. Value is always relative because it is based both on perceptions of the way a service is delivered and on initial customer expectations (Heskett, Jones, Loveman, Sasser, \& Schlesinger, 2008). Customer value takes the perspective of an organization's customers, considering what they want and believe that they get from buying and using a seller's product. This section addresses this customer- directed concept. Customer value define as perceived by customers determined by a seller. Finally, these perceptions typically involve a trade-off between what the customer receives (e.g., quality, benefits, worth, utilities) and what he or she gives up to acquire and use a product (e.g., price, sacrifices) (Woodruff, 1997). Syarifuddin \& Sofrosidiq (2012) added, building visitor value of customer value is the maximum effort must be made by tourism destination without having to spend big money, but the process is long 
There are many studies of customer perceived value as shown in Table 2. Since this study focusing on shopping tourism, hence, MALLVAL dimensions by M. I. El-Adly \& Eid (2015) assume to be most related for this study. The customer-perceived value constructs of shopping malls (MALLVAL) multidimensional construct comprising eight shopping values, namely, hedonic, utilitarian, self-gratification, epistemic, transaction, social interaction, spatial convenience, and time convenience. The result in this study found that all values play a role in purchasing decision.

Table 2: Studies of Perceived Value in Tourism and Hospitality

\begin{tabular}{|c|c|c|}
\hline Author(s) & $\begin{array}{l}\text { Approach } \\
\text { Method }\end{array}$ & Types of value \\
\hline (Nasution \& Mavondo, 2005) & Customer value & $\begin{array}{l}\text { Reputation for quality } \\
\text { Value for money } \\
\text { Prestige }\end{array}$ \\
\hline (Kotler et al., 2010) & Customer value & $\begin{array}{l}\text { Cost: monetary and non- } \\
\text { monetary } \\
\text { Benefit }\end{array}$ \\
\hline (Syarifuddin \& Sofrosidiq, 2012) & $\begin{array}{l}\text { Tourism } \\
\text { customer value }\end{array}$ & $\begin{array}{l}\text { Attractions } \\
\text { Accommodations facilities } \\
\text { Transportation facilities } \\
\text { Refreshments/catering (food } \\
\text { and drink) } \\
\text { Supporting facilities } \\
\text { Other infrastructures }\end{array}$ \\
\hline (Wahyuningsih, 2012) & Customer Value & $\begin{array}{l}\text { Functional value } \\
\text { Social Value } \\
\text { Emotional Value }\end{array}$ \\
\hline (Chen, 2013) & $\begin{array}{l}\text { Luxury } \\
\text { shopping value }\end{array}$ & $\begin{array}{l}\text { Conspicuous value } \\
\text { Snob effect } \\
\text { Bandwagon effect } \\
\text { Emotional value } \\
\text { Quality value }\end{array}$ \\
\hline (M. I. El-Adly \& Eid, 2015) & Shopping value & $\begin{array}{l}\text { Hedonic value } \\
\text { Utilitarian value } \\
\text { Self-gratification value } \\
\text { Epistemic value } \\
\text { Transaction value }\end{array}$ \\
\hline
\end{tabular}




\begin{tabular}{|c|c|c|}
\hline & & $\begin{array}{l}\text { Social interaction value } \\
\text { Spatial convenience value } \\
\text { Time convenience value }\end{array}$ \\
\hline $\begin{array}{l}\text { (Siamiloy, Suharyono, Kumadji, \& Utami, } \\
\text { 2015) }\end{array}$ & Customer value & $\begin{array}{l}\text { Utilitarian } \\
\text { Hedonic }\end{array}$ \\
\hline (Amoah, Radder, \& Eyk, 2016) & $\begin{array}{l}\text { Experience } \\
\text { Value }\end{array}$ & $\begin{array}{l}\text { Enjoyment } \\
\text { Entertainment } \\
\text { Escape } \\
\text { Atmospherics } \\
\text { Efficiency } \\
\text { Excellence } \\
\text { Economic value }\end{array}$ \\
\hline (Danurdara \& Hidayah, 2016) & Customer Value & $\begin{array}{l}\text { Cost } \\
\text { Benefit }\end{array}$ \\
\hline $\begin{array}{l}\text { (Gallarza, Arteaga-Moreno, Del Chiappa, \& } \\
\text { Gil-Saura, 2016) }\end{array}$ & Intrinsic values & $\begin{array}{l}\text { Entertainment } \\
\text { Aesthetics } \\
\text { Ethics } \\
\text { Spirituality as relaxation }\end{array}$ \\
\hline (Gallarza, Ruiz-molina, et al., 2016) & Perceived Value & $\begin{array}{l}\text { Utilitarian } \\
\text { Hedonic } \\
\text { Social }\end{array}$ \\
\hline (Martelo-Landroguez \& Martin-Ruiz, 2016) & Perceived value & $\begin{array}{l}\text { Monetary sacrifices } \\
\text { Non-monetary sacrifices } \\
\text { Quality } \\
\text { Performance } \\
\text { Disconfirmation experiences }\end{array}$ \\
\hline (Nazri, Raji, \& Zainal, 2016) & Perceived value & $\begin{array}{l}\text { Monetary price } \\
\text { Behavior price } \\
\text { Reputation } \\
\text { Emotional responses }\end{array}$ \\
\hline (Yang \& Mattila, 2016) & Customer value & $\begin{array}{l}\text { Utilitarian value } \\
\text { Hedonic value }\end{array}$ \\
\hline
\end{tabular}

\section{RESEARCH METHODS}

This study conducted primary data collection methods by distributing questionnaires. This study will use a structured questionnaire design. The convenience sampling method applied for this study is due to the absence of a definite population (unknown population) so the sample from 
this study was taken following the convenience of researchers in the data collection process. The survey in the form of a questionnaire was carried out and distributed in a place that had been planned and directly given to foreign tourists. The questionnaire was developed based on Eid \& El-Gohary (2015) research and modified by researchers using a literature review and adjusted for content validity.

The scope of the study in this study is the shopping tourism sector, tourists who are sampled in this study are tourists visiting the city of Bandung with the aim of shopping and tourists visiting the city of Bandung with other destinations but on the way they also do shopping activities. Places of research include: traditional markets, shopping centers, and factory outlets (FO) which are spread in Bandung City also at the airport by asking foreign tourists in advance whether they are doing shopping tours in the city of Bandung. The reason for limiting research to the context of shopping tourism is to look at the impact of foreign tourist spending so that it can help businessmen in the trade sector improve their business performance. To analyze business performance in non-financial performance, customer satisfaction is believed to be a good representation.

Data analysis technique done by exploratory data analysis techniques which are indicators used in several variables or can also be said as a factor of the initial or previous variable. This technique can presented in several stages and processes such as: formulating problems, load correlation matrix, determine the number of factors, rotation factors, interpretations factors, and determine the accuracy of the model.

\section{RESULT AND DISCUSSION}

\section{Respondents Characteristics}

Majority of respondents in this study were women aged between 21-30 years and single. In terms of occupation, the majority of respondents are private employees. The majority of visits to the city of Bandung are between 2-4 visits with friends and relations with a 4-6 day visit. The majority of them know the shopping tourism of Bandung City through the internet and can spend around \$100- \$500 per visit. From the descriptive results above, researchers can draw 
conclusions that foreign tourists feel interested in visiting Bandung seen from the frequency of visits more than once with the duration of visits between 4-6 days.

\section{Validity and Reliability Test}

Validity and reliability tests used to find whether all questions (indicators) in questionnaire is valid or not. Indicators said to be valid if the $r$ value is higher than $r$ table. Further, question can be stated to be reliable if the Cronbach alpha value is > 0.6 (Sujarweni, 2015). valid. The Reliability result found that all variables have alpha coefficient $>0.6$ whereby all indicators in the questionnaire are reliable.

\section{KMO and Bartlett's Test}

Kaiser Meyer Olkin Measure of Sampling Adequacy (KMO MSA) used to see whether all indicators are able to continue for next analysis. To be able to analyse analysis factor, the value of KMO should be at least 0.5 (Suliyanto, 2005). The result of KMO in this study is 0.901 which is higher than 0.5 . Therefore, next analysis can be proceed.

\section{Total Variance Explained}

Total Variance Explained used to see the result of the factor analysis and to see the number of new factors developed. The new factor should having the value of eigen value of higher than 1 (Suliyanto, 2005). The result of factor analysis shows that out of 26 indicators, there are 5 (five) new factors developed which having eigen value of higher than 1 . Those five factors are factors of tourist perceived value on shopping tourism in Indonesia.

\section{Rotated Component Matrix}

Rotated component matrix shows indicators distribution that has been extracted into factors that have been formed based on the loading factor after the rotation process has been carried out. Indicators that have a loading factor smaller than 0.5 are considered to have a weak contribution to the factors formed so that they must be eliminated or removed from the previously formed factor. Out of 26 indicators which analysed by Rotated Component Matrix, there are 3 indicators which have loading factor smaller than 0.5 , therefore it should be eliminated and final indicators used are 23 indicators. Next, naming the new factors will be based on indicators formed in each factors. 


\section{Interpretation of Factor}

Interpretation of factor done by forming indicators which have high factor loading to each new factors formed and named it based on indicators forming in the same factor. The result of cumulative variance for all new factors formed are $70.754 \%$ which consists of five factors. Those five factors named as: factor Emotional Value with variance of $48.067 \%$, factor Value for Money with variance of $7.715 \%$, factor Social Value with variance of $6.323 \%$, factor Hedonic Value with variance of $4.673 \%$, and factor Functional Value with variance of $3.977 \%$. Those factors described as follows:

1. First factor, Emotional Value having the highest Eigen value of 12.497 which consists of indicators: feel excited, sense of joy, fun, escape from life pressure, able to forget problems, release and relax, find it open.

2. Second factor, Value of Money having Eigen value of 2.006 which consists of indicators: satisfy all family members, varieties of activities, varieties of products and stores, get some bargain, on sale, and find some bargains.

3. Third factor, Social Value having Eigen value of 1.644 which consists of indicators: have fun and good memories with friends and family, spent time together with friends and family, socialize with friends and family.

4. Fourth factor, Hedonic Value having Eigen value of 1.215 which consists of indicators: feel happy, truly enjoyable, to see what is interesting or innovating.

5. Fifth factor, Functional value having Eigen value of 1.034 which consists of indicators: everyone can find their needs, get ideas about new trends of fashion, keep up with newest trends, open till late.

\section{E. CONCLUSION AND RECOMMENDATION}

Based on respondent characteristics, most of respondents are women aged between 21-30 years and single and it can be said that they feel interested in visiting Bandung seen from the frequency 
of visits more than once with the duration of visits between 4-6 days. The factors found in this study consist of five factors: (1) Emotional Value, (2) Value for Money, (3) Social Value, (4) Hedonic Value, and (5) Functional Value. The dominant factor is Emotional Value which having the highest Eigen value.

Based on the results of research and conclusions, there are several suggestions to improve this research in the future. First, there is a need for cooperation with the Government to overcome existing problems, such as infrastructure improvements to overcome congestion, flooding and other problems, so that foreign tourists are expected shopping activities with better conditions. Second, there is a need of improvement of the payment system. Facility in terms of use an EDC machine or simply swipe a credit card, making it easier for foreign tourists to make transactions. Further, the number of money changer facility needs to improve to make it easier for foreign tourists. Additionally, shopping centers in the city of Bandung need to pay attention to other aspects as supporting shopping tourism. Such as the availability of a culinary center, a gathering place for foreign tourists so as to provide more comfort for them and is expected to increase the growth of shopping tourism in the city of Bandung by providing recommendations to colleagues and family as well as making the next visit.

\section{REFERENCES}

Amoah, F., Radder, L., \& Eyk, M. van. (2016). Perceived experience value , satisfaction and behavioural intentions : A guesthouse experience. African Journal of Economic and Management Studies, 7(3), 419-433. https://doi.org/10.1108/AJEMS-10-2015-0121

Chen, N. (2013). Luxury shopping as a Factor in Destination Choice : Vienna, a case study. Modul University.

Christian, M., Fernandez-Stark, K., Ahmed, G., \& Gereffi, G. (2011). The Tourism Global Value Chain: Economic Upgrading and Workforce Development. Center on Globalization, Governance \& Competitiveness (CGGC). https://doi.org/10.13140/RG.2.1.4327.7284

Danurdara, A. B., \& Hidayah, N. (2016). Creating Customer Value and Its Implication To Customer Loyalty: An Empirical Study at Star Hotels in West Java, Indonesia. International 
Review of Management and Business Research, 5(2), 732-742.

El-Adly, M. I., \& Eid, R. (2015). Measuring the perceived value of malls in a non-Western context: the case of the UAE. International Journal of Retail \& Distribution Management, 43(9), 849-869. https://doi.org/10.1108/IJRDM-04-2014-0045

El-Adly, M. I., \& Eid, R. (2016). An empirical study of the relationship between shopping environment, customer perceived value, satisfaction, and loyalty in the UAE malls context. Journal of Retailing and Consumer Services, 31, 217-227. https://doi.org/10.1016/j.jretconser.2016.04.002

El-Adly, M. I., \& Eid, R. (2017). Dimensions of the perceived value of malls: Muslim shoppers' perspective. International Journal of Retail \& Distribution Management, 45(1), 40-56. https://doi.org/10.1108/IJRDM-12-2015-0188

Gallarza, M. G., Arteaga-Moreno, F., Del Chiappa, G., \& Gil-Saura, I. (2016). Intrinsic value dimensions and the value-satisfaction-loyalty chain: a causal model for services. Journal of Services Marketing, 30(2), 165. https://doi.org/10.1108/JSM-07-2014-0241

Gallarza, M. G., Ruiz-Molina, M. E., \& Gil-Saura, I. (2016). Stretching the value-satisfactionloyalty chain by adding value dimensions and cognitive and affective satisfactions: A causal model for retailing. Management Decision, 54(4), 981-1003. https://doi.org/https://doi.org/10.1108/MD-07-2015-0323

Gallarza, M. G., Ruiz-molina, M. E., Gil-saura, I., Gallarza, M. G., Ruiz-molina, M. E., \& Gilsaura, I. (2016). Stretching the value-satisfaction- loyalty chain by adding value dimensions and cognitive and affective satisfaction: A causal model for retailing. Management Decision, 54(4), 981-1003. https://doi.org/10.1108/MD-07-2015-0323

Hertinmalyana, M., Rahayu, A. H., \& Wati, R. R. (2012). Analysis of Demand and Consumption of International Visitors to Indonesia (from selected countries).

Heskett, J. L., Jones, T. O., Loveman, G. W., Sasser, W. E. J., \& Schlesinger, L. A. (2008). Putting the service-profit chain to work. Harvard Business Review, 118-129. https://doi.org/10.1037/e459772008-014 
I Gede Pitara. (2016). Fakta Traveling - Turis Asal Negara Ini yang Paling Royal Belanja di Destinasi Wisata Indonesia - TribunTravel.com.

Jucan, C. N., \& Jucan, M. S. (2013). Travel and Tourism as a Driver of Economic Recovery. Procedia Economics and Finance, 6(13), 81-88. https://doi.org/10.1016/S22125671(13)00117-2

Khuong, M. N., \& Ha, T. T. (2014). The Influences of Push and Pull Factors on the International Leisure's Return Intention to Ho Chi Minh City. Vietnam - A mediation Analysis of Destination Satisfaction. International Journal of Trade, Economics and Finance, 5(6).

Kotler, P., Bowen, J. T., \& Makens, J. C. (2010). Marketing for Hospitality and Tourism (5th Editio). Prentice Hall.

Martelo-Landroguez, S., \& Martin-Ruiz, D. (2016). Managing knowledge to create customer service value. Journal of Service Theory and Practice, 26(4), 471-496. https://doi.org/10.1108/JSTP-06-2014-0137

Mcewen, D., \& Bennett, O. (2010). Seychelles Tourism Value. Seychelles.

Mehta, S., Jain, A., \& Jawale, R. (2014). Impact of Tourism on Retail Shopping in Dubai. International Journal of Trade, Economics and Finance, 5(6), 530-535. https://doi.org/10.7763/IJTEF.2014.V5.428

Meng, F., \& Xu, Y. (2012). Tourism shopping behavior: planned, impulsive, or experiential? International Journal of Culture, Tourism and Hospitality Research, 6(3), 250-265. https://doi.org/10.1108/17506181211246401

Nasution, H. N., \& Mavondo, F. T. (2005). The Impact Of Service Quality On Customer Value In The Hotel Industry. In ANZMAC 205 Conference: Tourism Marketing (pp. 72-79).

Nazri, M., Raji, A., \& Zainal, A. (2016). The effect of customer perceived value on customer satisfaction : A case study of Malay upscale restaurants. Malaysian Journal of Society and Space, 3(3), 58-68.

Oh, Y.-J. (2007). An exploration of tourist shopping. ProQuest Dissertations and Theses, (August), 157. 
PIDII. (2016). Development of Tourism Destination Indonesia.

Puskompublik. (2012). WIsata Belanja, WIsata Kuliner dan Golf Diminati Masyarakat Malaysia.

Raluca, D. C., \& Gina, S. (2003). THE IMPACT OF SHOPPING TOURISM ON THE FUTURE OF LEISURE SERVICES. Organization Behaviour for Leisure Services, 67-72.

Siamiloy, J. E., Suharyono, Kumadji, S., \& Utami, H. N. (2015). Relationship Marketing As Amediator of Destination Image and Customer Value Onbehavioral Intention (A Study on Customers of Tourist Destinations in Maluku Province). IOSR Journal of Business and ManagementVer. III, 17(3), 2319-7668. https://doi.org/10.9790/487X-17337279

Sundström, M., Lundberg, C., \& Giannakis, S. (2011). Tourist shopping motivation: go with the flow or follow the plan. International Journal of Quality and Service Sciences, 3(2), 211224. https://doi.org/10.1108/17566691111146104

Syarifuddin, D., \& Sofrosidiq, R. S. (2012). INCREASING NUMBER OF TOURISTS BY MEANS OF BUILDING TOURIST VALUE ( Implementing how to increase customer value at a tourism destination. The 13th Malaysia Conference on Economics, Management and Accounting (MIICEMA), (October 2012), 14.

Timothy, D. J. (2005). Shopping Tourism, Retailing, and Leisure.

UNWTO. (2014). Global Report on Shopping Tourism. https://doi.org/10.1007/s13398-014$0173-7.2$

UNWTO. (2016a). Shopping Tourism, key for destination marketing.

UNWTO. (2016b). Tourism Highlights. https://doi.org/10.18111/9789284418145

Wahyuningsih. (2012). The Effect of Customer Value on Behavioral Intentions in Tourism Industry. International Research Journal of Business Studies, 5(1).

Woodruff, R. B. (1997). Customer Value: The Next Source for Competitive Advantage. Journal of the Academy of Marketing Science, 25(2), 139-153. https://doi.org/10.1007/BF02894350

Yang, W., \& Mattila, A. S. (2016). Why do we buy luxury experiences? Measuring value perceptions of luxury hospitality services. International Journal of Contemporary 
Vol. 4 No. 1 Firm Journal of Management Studies

Hospitality Management, 28(9), 1848-1867.

https://doi.org/http://dx.doi.org/10.1108/09564230910978511

Yuan, J., Fowler, D. C., Goh, B. K., \& Lauderdale, M. K. (2013). Mexican cross-border shoppers' motivations to the USA. International Journal of Culture, Tourism and Hospitality Research, 7(4), 394-410. https://doi.org/10.1108/ijcthr-02-2013-0004 